\title{
STUDIES ON PICOPHYTOPLANKTON IN THE SOUTHERN GULF OF MEXICO: RECOGNITION OF PICOPROKARYOTES AND ABUNDANCES OF PICOPHYTOPLANKTON DURING "DRY SEASON"
}

\author{
Aldo Aquino-Cruz ${ }^{l}$, David Uriel Hernández-Becerril ${ }^{l, *}$, Martha Signoret-Poillon ${ }^{2}$, \\ David Alberto Salas-de-León ${ }^{l}$ and María Adela Monreal-Gómez ${ }^{l}$
}

\author{
${ }^{1}$ Universidad Nacional Autónoma de México \\ (Circuito Exterior, S/N, Cd. Universitaria, Apartado Postal 70-305, C.P. 04510, México, D.F., México) \\ ${ }^{2}$ Universidad Autónoma Metropolitana-Xochimilco - Departamento El Hombre y su Ambiente \\ (Calz. Del Hueso 1100, Col. Villa Quietud, 04960, México, D.F., México)
}

*Corresponding author: dhernand@cmarl.unam.mx

\begin{abstract}
A B S T R A C T
The abundance and distribution of total autotrophic picophytoplankton (PFP), temperature, salinity, PAR, and chlorophyll a were determined in two presumably contrasting environments: (1) two coastal areas (close to the mouths of three rivers), and (2) one oceanic area (Campeche Canyon), of the southern Gulf of Mexico, during the "dry season" (June-July, 2004). The picoprokaryotes Prochlorococcus and Synechococcus were identified by TEM, whereas Synechococcus and picoeukaryotes populations were also recognized by flow cytometry. The highest PFP abundance (1.67×105 cells ml-1) was found in shallow waters ( 10 m depth) around the Grijalva-Usumacinta river mouth, followed by that found at a station close to the Coatzacoalcos River $(1.19 \times 105$ cells ml1); PFP abundances in the Campeche Canyon were usually lower (maximum $1.53 \times 104$ cells ml-1). Greater variability in PFP abundances was found in coastal stations than in oceanic waters, and weak relationships appeared between the patterns of chlorophyll a and PFP abundance. Peaks of PFP were detected in both coastal and more oceanic areas, but in the Campeche Canyon they were located deeper $(60 \mathrm{~m})$, relatively closer to the deep maximum of chlorophyll (located at about $75 \mathrm{~m}$ ). Results suggest that PFP populations include a substantial photosynthetic component in both coastal and oceanic waters of the southern Gulf of Mexico.
\end{abstract}

\section{RESUMO}

Abundância e distribuição do picofitoplâncton autotrófico total (PFP), temperatura, salinidade, PAR e clorofila-a, foram determinados em dois ambientes presumivelmente diferentes: (1) duas áreas costeiras (perto da foz de três rios) e (2) uma área oceânica (Campeche Canyon), ambas situadas ao sul do Golfo do México, durante a "estação seca" (Junho-Julho, 2004). Os picoprocariontes Prochlorococcus e Synechococcus foram identificados por TEM, e as populações de Synechococcus e de picoeucariontes também foram reconhecidas por citometria de fluxo. A maior abundância de PFP $(1,67 \times 105$ células ml-1) foi encontrada em águas rasas $(\sim 10 \mathrm{~m}$ de profundidade $)$ em torno dos rios Grijalva Usumacinta, seguida de uma estação perto do Rio Coatzacoalcos $(1,19 \times 105$ células ml-1). As abundâncias de PFP em Campeche Canyon foram geralmente menores (máximo 1,53 × 104 células ml-1). A maior variabilidade em abundâncias de PFP foi encontrada em estações costeiras quando comparado às águas oceânicas, e quase não houve correlação entre os padrões de clorofila-a e abundância de PFP. Picos de PFP foram detectados nas áreas costeiras e oceânicas, mas em Campeche Canyon localizaram-se em maior profundidade $(60 \mathrm{~m})$, relativamente mais perto do local onde se registrou o máximo de clorofila (cerca de $75 \mathrm{~m}$ ). Os resultados sugerem que as populações de PFP englobam um componente fotossintético substancial em ambas as águas costeiras e oceânicas do sul do Golfo do México.

Descriptors: Abundance, Distribution, Picophytoplankton, Prochlorococcus, southern Gulf of Mexico, Synechococcus.

Descritores: Abundância, Distribuição, Picofitoplâncton, Prochlorococcus, sul do Golfo do México, Synechococcus. 


\section{INTRODUCTION}

The term autotrophic picoplankton or picophytoplankton (PFP) refers to the smallest photosynthetic prokaryote and eukaryote organisms of aquatic ecosystems with a cell size between 0.5 and $3 \mu \mathrm{m}$, of worldwide distribution in marine waters (STOCKNER, 1988; PARTENSKY et al., 1999; MAN-AHARONOVICH et al., 2010; CERINO et al., 2012). This photosynthetic community of microorganisms has shown a great and unexpected species diversity (LE GALL et al., 2008; NOT et al., 2009; MOON-VAN DER STAAY et al., 2001; MANAHARONOVICH et al., 2010). Picoprokaryotes, basically composed of the cyanobacteria Prochlorococcus and Synechococcus are generally a dominant photosynthetic component in oligotrophic waters (AGAWIN and AGUSTÍ, 2005; BERTILSSON et al., 2005; GROBet al., 2007), but may also be important in more eutrophic waters in coastal areas (CHEN et al., 2011; MITBAVKAR et al., 2012). Eukaryotic picoplankton include several classes of phytoplankton (Haptophytes, Pelagophyceae, Prasinophyceae, etc.), they are of worldwide distribution in coastal waters and their dynamic has been linked to the large amounts of biomass found in phytoplankton communities (NOT et al., 2004; MARIE et al., 2010).

The southern Gulf of Mexico is a dynamic marine ecosystem where many physical and biological processes occur in both coastal and oceanic waters (SALAS-DE-LEÓN et al., 2004, 2008; SIGNORET et al., 2006). One of the most important hydrological aspects of this area is the influence of both the Coatzacoalcos and Grijalva-Usumacinta Rivers, this latter discharging the second-largest volume of freshwater into the Gulf of Mexico (YÁÑEZARANCIBIA and DAY, 2004, MÉXICO, 2008). The climate in this tropical environment presents a dry and a rainy season that modify the hydrodynamic and freshwater influence on the continental shelf (TORRES-BEJARANO et al., 2012). The dry season in the southern Gulf is normally associated with both tide penetration up the river (TORRES-BEJARANO et al., 2012) and the slight influence of terrigenous material (nutrient load) on the continental shelf, which together result in decreasing concentrations of chlorophyll $a$ in the water column (SIGNORET et al., 2006). During the rainy season, a considerable amount of continental water flows downstream to the mouth on the Gulf of Mexico and induces thermal and haline fronts associated with river plumes in the region of the Coatzacoalcos and Grijalva-Usumacinta Rivers (SIGNORET et al., 2006; HERNÁNDEZ-BECERRIL et al., 2008). Average flow rates in the Coatzacoalcos River have attained 405 and $1104.9 \mathrm{~m}^{3} \mathrm{~s}^{-1}$, respectively, during the dry and rainy season (TORRES-BEJARANO et al., 2012), while the Grijalva-Usumacinta River has reached up to $2154 \mathrm{~m}^{3}$ $\mathrm{s}^{-1}$ (ALVÁREZ-GÓNGORA et al., 2012). Total mean natural surface runoff recorded 39482 and 117546 $\mathrm{hm}^{3} /$ year in the Coatzacoalcos and GrijalvaUsumacinta Rivers, respectively (CONAGUA, 2008). Nutrient inputs onto the continental shelf in the southern Gulf are known to control biodiversity and primary productivity in oligotrophic and coastal regions (ALVÁREZ-GÓNGORA et al., 2012). Due to the fact that the Coatzacoalcos River has been drastically contaminated by many anthropogenic sources over the years (mainly because of land use change, urban pollution and petrochemical production activities), water discharges in the Coatzacoalcos region have damaged extensive coastal ecosystems and represent a threat to aquatic marine life as well as to humans through the consumption of contaminated seafood (RUIZ-FERNÁNDEZ et al., 2012).

The coastal waters of the southern Gulf exhibit a remarkable temporal and spatial variability in the distribution of chlorophyll $a$, which is dependent on the interaction of temperature, salinity, irradiance, nutrient availability, and water circulation in the water column (SIGNORET et al., 2006). The Campeche Canyon is a geomorphological feature encountered in the oceanic waters of the southern Gulf of Mexico ( 2400 $\mathrm{m}$ depth),in the region of which currents, gyres, and atmospheric conditions impact various biological processes throughout the year (SALAS-DELEÓN et al., 2004). In this region autotrophicheterotrophic biogeochemical processes are met with which lead to a deepening of the chlorophyll maximum (to between 78 and $89 \mathrm{~m}$ ) and the depth of the euphotic zone as a result of the influence of an anticyclonic eddy (SALAS-DE-LEÓN et al., 2004).

There are few studies of PFP in this region. Hernández-Becerril et al. (2012) studied accessory pigments associated with PFP and the picoeukaryote fraction, and found that Prorochlorococcus, Synechococcus, and some picoeukaryotes (Micromonas pusilla) were numerically important and distributed throughout the euphotic zone of the southern Gulf of Mexico.

The specific aims of this study were to: (1) describe some environmental and hydrographic conditions in possible association with the abundance of picophytoplankton in the study area during the "dry season", (2) recognize picoprokaryote organisms by ultrastructural studies (transmission electron microscopy, TEM) and flow cytometry, and (3) determine the abundances and vertical distribution of total picophytoplankton in two presumably contrasting environments, i.e, coastal and oceanic areas, of the southern Gulf of Mexico. 


\section{Material ANd Methods}

\section{Study Area}

This investigation was conducted in the southern Gulf of Mexico, located between 18-21 ${ }^{\circ} \mathrm{N}$ and $92-95^{\circ} \mathrm{W}$ (Fig. 1). This region pertains to a tropical marine ecosystem with atmospheric and surface water temperatures above $29^{\circ} \mathrm{C}$ during summer (TOLEDO, 1996). The Coatzacoalcos and Grijalva-Usumacinta Rivers are two hydrological components that transport large amounts of nutrients of terrigenous origin onto the continental shelf. The average annual discharge of the Grijalva-Usumacinta and Coatzacoalcos river is $115,536 \mathrm{hm}^{3}$ and 32,752 $\mathrm{hm}^{3}$, respectively (MÉXICO, 2008). Mesotrophic and eutrophic waters have been encountered in association with the continental shelf while oligotrophic waters dominate the oceanic environment (SIGNORET et al., 2006). Chlorophyll- $a$ fluorescence has indicated significant amounts of photosynthetic biomass associated with the thermocline depth and low-light conditions (SALAS-DE-LEÓN et al., 2004; SIGNORETet al., 2006). In summer (the dry season) stratified waters occur in the southern Gulf of Mexico, with a thermocline at depths of more than $70 \mathrm{~m}$, generally associated with the Campeche Canyon (ESPINOSA-FUENTES and FLORES-COTO, 2004). A cyclonic gyre develops in autumn $(<150 \mathrm{~km}$ diameter) when colder water masses rise to the surface and reduce the thermocline's depth (MONREALGÓMEZ and SALAS-DE-LEÓN, 1997). In addition, the influence of energetic and warm water masses from the Caribbean Sea, brought by the Yucatan current, lead to the formation of anticyclonic and cyclonic gyres that carry planktonic organisms into the southern Gulf of Mexico (SANVICENTE-AÑORVE et al., 2000). The continental shelf receives large amounts of nutrients from the water discharges of the Coatzacoalcos and Grijalva-Usumacinta Rivers (Fig. 1), the latter of which is considered the second greatest provider of continental water for the Gulf of Mexico (YÁÑEZ-ARANCIBIA and DAY, 2004).

\section{Collection of Water Samples}

Sampling was carried out on board the R/V "Justo Sierra", on the cruise PROMEBIO IX, during the "dry season" (June-July, 2004). Sampling stations in the southern Gulf of Mexico were located in two coastal areas (eight stations in all: three in the vicinity of the Coatzacoalcos River and five around the Grijalva-Usumacinta Rivers) and in an oceanic area (three stations at the Campeche Canyon) (Fig. 1). Water samples for studying picoplankton were collected from the water column with Niskin bottles ( 8 L) attached to a CTD-Rosette system (Neil Brown Mark III) every 4-10 m over the continental shelf where depths were less than $40 \mathrm{~m}$, otherwise samples were collected at 10, 20, 40,60, 80, 100, 120, 150 and $180 \mathrm{~m}$. At each sampling station, CTD casts recorded temperature and salinity throughout the water column. Vertical profiles of both chlorophyll $a$ (deep chlorophyll maximum, DCM) and $\mathrm{PAR}_{0}$ (photosynthetic active radiation) were measured with a passive fluorometer (Biospherical Instruments, model PNF-300) based on in vivo fluorescence and an algorithm provided by the manufacturer.

\section{Identification of Picoprokaryote Cells by TEM}

Picoprokaryote organisms were identified by transmission electron microscopy (TEM) (JEOL 1200 CX). A $300 \mathrm{ml}$ water sample with a high concentration of phytoplankton was centrifuged at $10,500 \mathrm{~g}$ for 15 min. Cell pellets were separated from the supernatant by decantation and fixed in $5 \mathrm{ml}$ of filtered seawater $(0.2 \mu \mathrm{m})$ with glutaraldehyde (3\% final concentration) for $24 \mathrm{~h}$ at $4{ }^{\circ} \mathrm{C}$. Cells were post-fixed with osmium tetroxide $(2 \%)$ and phosphate buffer $(100 \mathrm{mM})$ for $2 \mathrm{~h}$. Samples were dehydrated through an ethanol series $(10,30,50,70,90,100 \%)$. Cells were then embedded in epoxy resin, with posterior polymerization in an oven $\left(60^{\circ} \mathrm{C}\right)$ for $48 \mathrm{~h}$. Thin sections of the embedded cells were made every $100 \mathrm{~nm}$ using an ultramicrotome Reichert-Jung. The cells were then mounted on grids and treated conventionally for contrast (ammonium acetate and lead citrate) before observation by TEM.

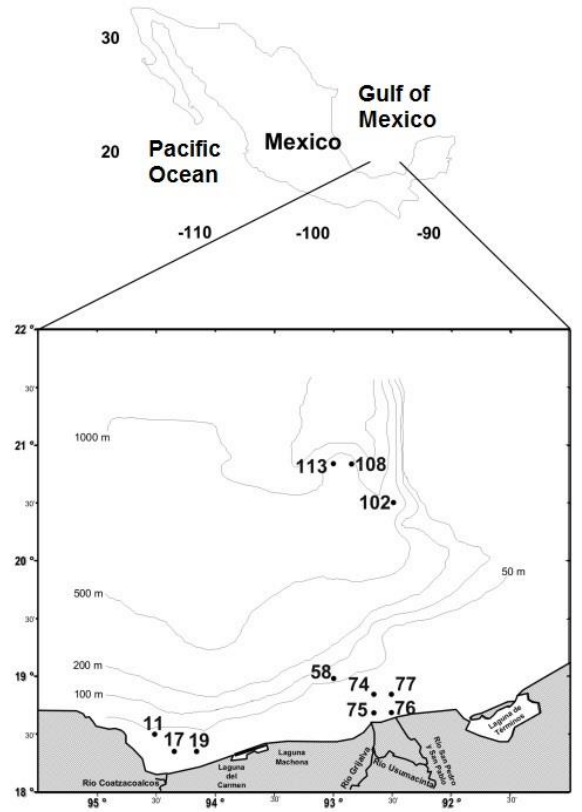

Fig. 1. Map of the southern Gulf of Mexico, showing the study area, with the eleven stations placed in two coastal areas (Sta. 11-19 and Sta. 58-77) and one oceanic area (Campeche Canyon) (Sta. 102-113). 


\section{Cell Counts by Epifluorescence Microscopy}

$150 \mathrm{ml}$ of sea water were collected at each depth, fixed with paraformaldehyde $(1 \%$ final concentration) in dark glass bottles and stored at $-15^{\circ}$ C. Samples were maintained at this temperature until analysis. Samples were thawed out in water $\left(\sim 37^{\circ} \mathrm{C}\right)$ and an aliquot of $15-25 \mathrm{ml}$ of sea water was filtered by hand through a nitrocellulose black membrane $(0.22 \mu \mathrm{m})$ using a filter unit attached to a $60 \mathrm{ml}$ syringe. Filters with the biological material were mounted on microscope slides with a drop of immersion oil (Zeiss) on the top and bottom of the filters before they were secured with a cover slide. Picoplankton cells were identified and quantified by natural fluorescence under an epifluorescence microscope (Olympus BX-40) equipped with an excitation filter with a wavelength at $470 \mathrm{~nm}$ (blue light), a dichroic filter (495 nm) and an emission filter $(515 \mathrm{~nm})$ manufactured by Chroma Technology. A total of 300-350 cells were counted at each sampling depth and cell concentration was inferred in accordance with the equation:

$$
N=\frac{n}{V} \times \frac{s}{P}
$$

where $N=$ total number of PFP cells per $\mathrm{ml}^{-1} ; \mathrm{n}=$ total number of cells counted on filter, $V=$ volume of sample filtered; $S=$ total filter area $\left(\mathrm{cm}^{2}\right) ; P=$ area where cells were counted $\left(\mathrm{cm}^{2}\right)$. This study was limited to distinguishing between prokaryote and eukaryote cells since natural fluorescence was too dim to distinguish red from orange. Therefore, the cell counts shown in this study refer to the total number of PFP (prokaryote and eukaryote) cells.

\section{Cells Analysis by Flow Citometry}

In general, procedures for studying picophytoplankton samples by flow cytometry (sampling, identifying and counting picophytoplankton) followed recommendations by Marie et al. (1999). Aliquots of $5 \mathrm{ml}$ from selected bottle samples were placed into cryovials and kept frozen in liquid nitrogen until analysis by flow cytometry. Approximately 1-2 ml of thawed samples were analyzed by flow cytometer (FACScalibur, Becton Dickinson). Three fluorescences were used: FL1 (green fluorescence), FL2 (red fluorescence) and FL3 (orange fluorescence), and Polyscience beads of 1 $\mu \mathrm{m}\left(5-10 \mu \mathrm{l}\right.$ at bead concentrations of $10^{5}$ beads $\left.\mathrm{ml}^{-1}\right)$ were also used for calibration. Acquisitions varied from 50 to $100 \times 10^{3}$ events, depending on the cells density. The cell quest program was used to analyze data.

\section{Results}

\section{Hydrographic Conditions and Chlorophyll a}

Table 1 shows data of total depth, thermocline depth, $\mathrm{PAR}_{0}$, total picophytoplankton abundance, and chlorophyll $a$ found in the stations sampled in the southern Gulf of Mexico. Coastal Stations (11, 17 and 19) in the vicinity of the Coatzacoalcos River were relatively shallow, with depths of less than $65 \mathrm{~m}$. The mixing layer depth at those stations was $\sim 15 \mathrm{~m}$ with water temperatures between 25 and $27^{\circ} \mathrm{C}$ (Fig. 2, Table 1). The Coatzacoalcos River's discharge had no influence on the water of the continental shelf since salinity was never below 36 . The depth of the photic zone $(1 \%$ $\mathrm{PAR}_{0}$ ) was detected at $57 \mathrm{~m}$ (Sta. 11) and $37 \mathrm{~m}$ (Sta 17), whereas $46 \%$ of $\mathrm{PAR}_{0}$ reached the bottom at Station 19 (Fig. 2, Table 1). The chlorophyll maximum (CM) was very weak, except at Station 19 (Table 1), and was detected below the mixed layer, at $33 \mathrm{~m}$ (Sta. 11), $26 \mathrm{~m}$ (Sta. 17), and $19 \mathrm{~m}$ (Sta. 19) (Fig. 2).

Coastal stations distributed in the proximity of the Grijalva-Usumacinta Rivers were rather shallow, between 10 and $25 \mathrm{~m}$ (Sta. 74-77) (Fig. 2), whereas towards the northwest, linked to the narrow end of the continental shelf, the depth reached $120 \mathrm{~m}$ (Sta. 58) (Fig. 2). Water temperature did not vary substantially in the water column, except at Stations 77 and 58, where the mixing layer reached depths of $17 \mathrm{~m}$ and $33.5 \mathrm{~m}$, respectively (Fig. 2, Table 1); a well-defined thermocline was found at Station 58 (Fig. 2, Table 1). All stations showed salinities $>36$, with DCM towards the bottom and irradiances spanning the entire water column, except at Station 58 $\left(1 \% \mathrm{PAR}_{0}\right.$ at $\left.109 \mathrm{~m}\right)$ (Fig. 2, Table 1). The vertical distribution of chlorophyll showed no clearly defined pattern, and the layers of CM were not apparent, except at Station 58, where a CM was located at $66 \mathrm{~m}$ (Fig. 2, Table 1), and at Station 76 (close to the surface, $5.5 \mathrm{~m}$, Fig. 2) where the chlorophyll concentration attained the highest value found in this study (2.81 $\mathrm{mg} \mathrm{m}^{-3}$ ) (Table 1$)$.

Stations located over the Campeche Canyon had maximum depths $\sim 2379 \mathrm{~m}$ (Table 1). The mixing layer depth was found between 30-42.5 m, with warm temperatures $\sim 28.5^{\circ} \mathrm{C} \quad$ (Fig. 3); well-defined thermoclines were found at all three Stations. In this area (Sta. 102-113) the photic zone $\left(1 \% \mathrm{PAR}_{0}\right)$ varied between $81.5-118.5 \mathrm{~m}$, with salinities of from 35.5 to 36.6 (Fig. 3). Chlorophyll $a$ concentrations were rather low, and the chlorophyll maximum reached $0.35 \mathrm{mg}$ $\mathrm{m}^{-3}$ at both 21 and $78 \mathrm{~m}$ depths at Station 102, whereas concentrations of 0.49 and $0.45 \mathrm{mg} \mathrm{m}^{-3}$ were found at around 76-78 m depth at Stations 108 and 113 (Fig. 3, Table 1). 
Table 1. Total depth, thermocline depth, depth of $1 \%$ PAR, maximum abundance of picoplankton, and deep chlorophyll maximum encountered at coastal and oceanic stations in the southern Gulf of Mexico. NP: not present; *max. indicates maximum percentage of irradiance detected at the bottom.

\begin{tabular}{|c|c|c|c|c|c|}
\hline Station & $\begin{array}{c}\text { Depth } \\
\text { (m) }\end{array}$ & $\begin{array}{l}\text { Thermocline depth } \\
\text { (m) }\end{array}$ & $\begin{array}{l}\text { Depth of 1\% } \\
\text { PAR (m) }\end{array}$ & $\begin{array}{c}\text { Maximum abundance } \\
\left(\text { cells } \mathbf{~ m l}^{-1}\right)\end{array}$ & $\begin{array}{l}\text { Maximum chlorophyll } a \\
\left(\mathrm{mg} \mathrm{m}^{-3}\right)\end{array}$ \\
\hline 11 & 68 & 14 & 57 & $8.12 \times 10^{4}$ at $32 \mathrm{~m}$ & 0.44 at $33 \mathrm{~m}$ \\
\hline 17 & 42 & 13.5 & 31 & $1.19 \times 10^{5}$ at $5 \mathrm{~m}$ & 0.46 at $26 \mathrm{~m}$ \\
\hline 19 & 34 & 14.5 & $*_{\max } 46 \%$ & $8.72 \times 10^{4}$ at $12 \mathrm{~m}$ & 1.98 at $19 \mathrm{~m}$ \\
\hline 58 & 120 & 33.5 & 109 & $2.78 \times 10^{4}$ at $20 \mathrm{~m}$ & 0.91 at $66 \mathrm{~m}$ \\
\hline 74 & 25 & $\mathrm{NP}$ & $* \max .10 \%$ & $9.54 \times 10^{4}$ at $21 \mathrm{~m}$ & 0.60 at $21.6 \mathrm{~m}$ \\
\hline 75 & 14 & 11.4 & $* \max .20 \%$ & $1.16 \times 10^{5}$ at $5 \mathrm{~m}$ & 1.20 at $12.5 \mathrm{~m}$ \\
\hline 76 & 10 & $\mathrm{NP}$ & $*_{\max } 24.5 \%$ & $1.67 \times 10^{5}$ at $9 \mathrm{~m}$ & 2.81 at $5.5 \mathrm{~m}$ \\
\hline 77 & 21 & 16.5 & $*_{\max } 58 \%$ & $9.68 \times 10^{4}$ at $10 \mathrm{~m}$ & 1.49 at $17 \mathrm{~m}$ \\
\hline 102 & 2371 & 30 & 90 & $1.53 \times 10^{4}$ at $10 \mathrm{~m}$ & 0.35 at $21 \mathrm{~m}$ \\
\hline 108 & 2219 & 40 & 118.5 & $1.25 \times 10^{4}$ at $60 \mathrm{~m}$ & 0.49 at $77 \mathrm{~m}$ \\
\hline 113 & 2196 & 42 & 81.5 & $1.32 \times 10^{4}$ at $60 \mathrm{~m}$ & 0.45 at $76 \mathrm{~m}$ \\
\hline
\end{tabular}
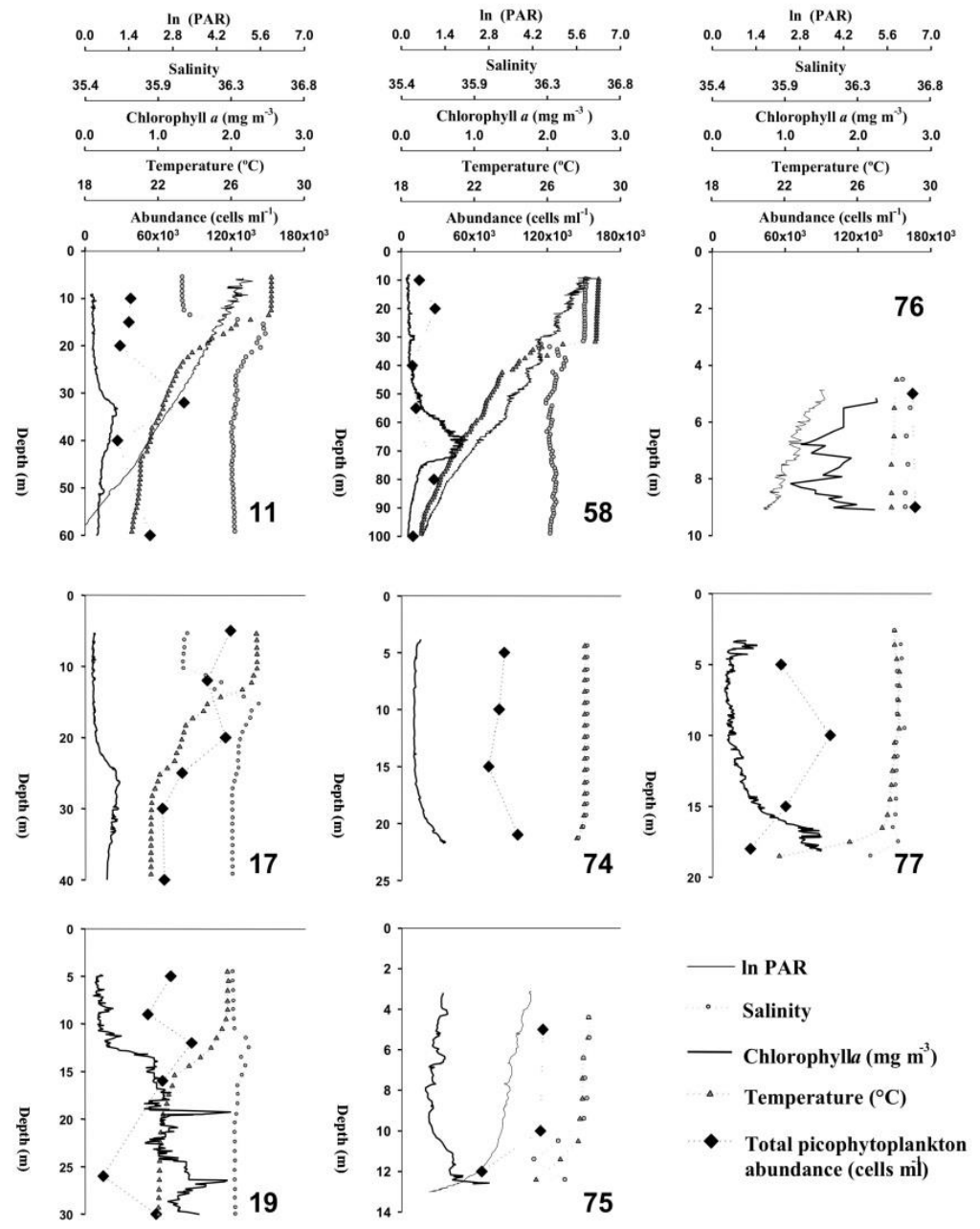

Fig. 2. Vertical profiles of some environmental variables, chlorophyll $a$ and picophytoplankton in two coastal areas: Sta. 11-19 (around the Coatzacoalcos River) and Sta. 58-77 (around the Grijalva-Usumacinta Rivers). 


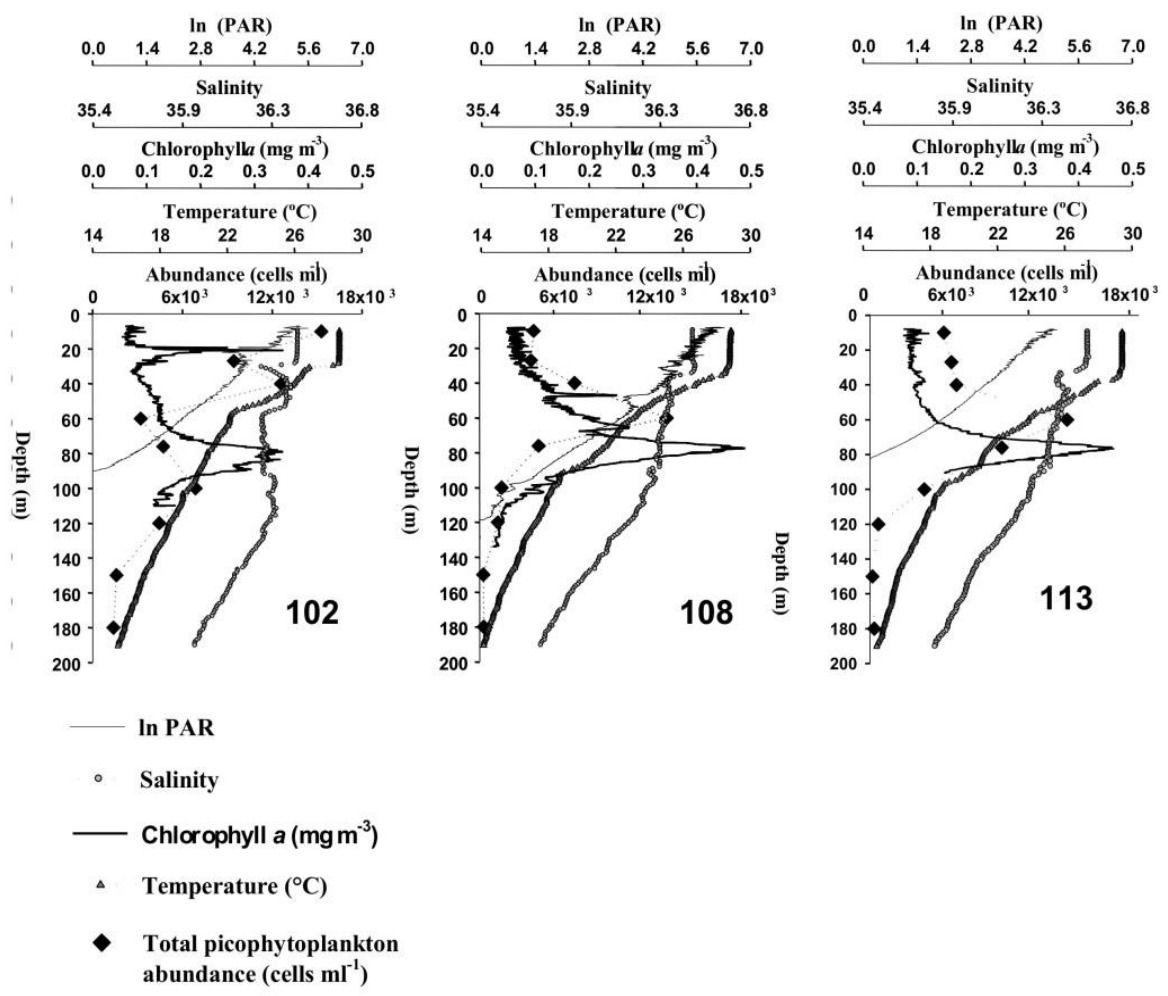

Fig. 3. Vertical profiles of some environmental variables, chlorophyll $a$ and picophytoplankton in one oceanic area: Sta. 102-113 (Campeche Canyon).

Identification of Picophytoplankton Cells

Picoprokaryote organisms were successfully recognized for the first time in the southern Gulf of Mexico by TEM, in terms of shape, size and ultrastructure. Both Prochlorococcus (Fig. 4a) and Synechococcus (Figs 4b-d) cells were identified: the Prochlorococcus cells presented a spherical to subspherical shape and sizes varying between 0.58 and $0.65 \mu \mathrm{m}$ diameter, some of them with virus attached (Fig. 4a, arrow), whereas Synechococcus cells were more elongated (Figs 4c, d), solitary or in clumps (up to three cells) (Fig. $4 \mathrm{c}$ ) and varied between 0.72 and $0.98 \times 0.41$ and $0.73 \mu \mathrm{m}$ in size, with some cells found in division (Fig. 4b). They were present in all the samples obtained and analyzed throughout this study.

Additionally, picoeukariote populations (even two populations were observed, Fig. 5, $26 \mathrm{~m}$ ) could be recognized by flow cytometry by showing high red fluorescence (due to chlorophyll $a$ ) and very low orange fluorescence, whereas Synechococcus populations were relatively easily identified by the combination of red and orange fluorescences (Figs 5, 6); Prochlorococcus populations were probably masked by the electronic noise and could not be recognized positively (Figs 5, 6). However, unfortunately, cell counting by flow cytometry provided an overestimation of cells when the calculations were made and the data proved to be unreliable for corrections.

\section{Abundance and Distribution of Picophytoplankton}

Total abundances of picophytoplankton, obtained from epifluorescence microscopy analysis, were different as between the coastal areas and the most oceanic one, with higher values (of one order of magnitude) in the former than in the latter. In general, the vertical distribution of these abundances showed irregular patterns, especially in the Stations located in coastal areas, where only very shallow Stations (74 and 76) exhibited a homogeneous distribution (Fig. 2). As regards Stations of the Campeche Canyon, Station 102 showed the highest abundance close to the surface $(10 \mathrm{~m})$, whereas at Stations 108 and 113 the maximum abundances were located around $60 \mathrm{~m}$ (Fig. 3, Table 1). 

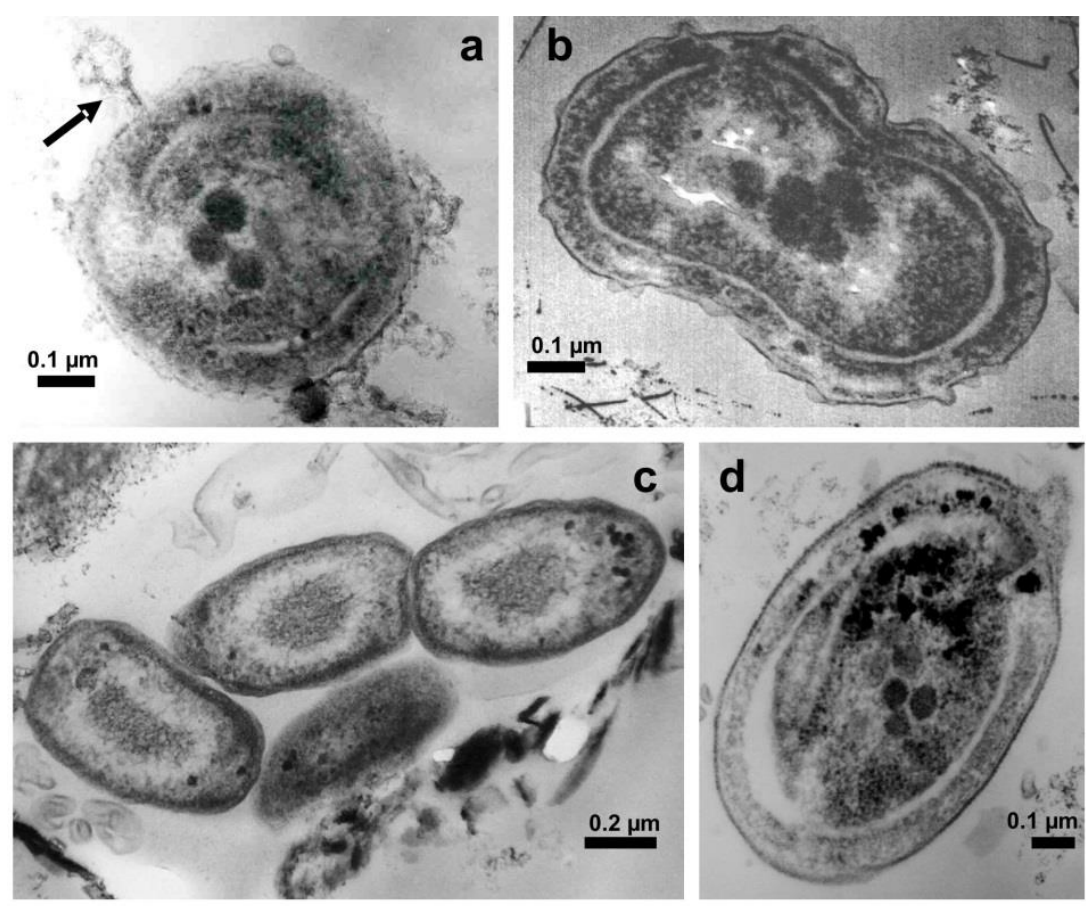

Fig. 4. Picoprokaryotes cells, TEM. Fig. 4a.Prochlorococcuscell showing some ultrastructural characteristics and one virus attached (arrow) $(0.64 \mu \mathrm{m}$ diameter). Fig. 4b.Synechococcus cell in division $(1.12 \mu \mathrm{m}$, longest axis). Fig. 4c.Three Synechococcus cells $(0.72 \times 0.41 \mu \mathrm{m})$.Fig. $4 \mathrm{~d}$. Detail of one Synechococcus cell $(0.98 \times 0.73 \mu \mathrm{m})$.

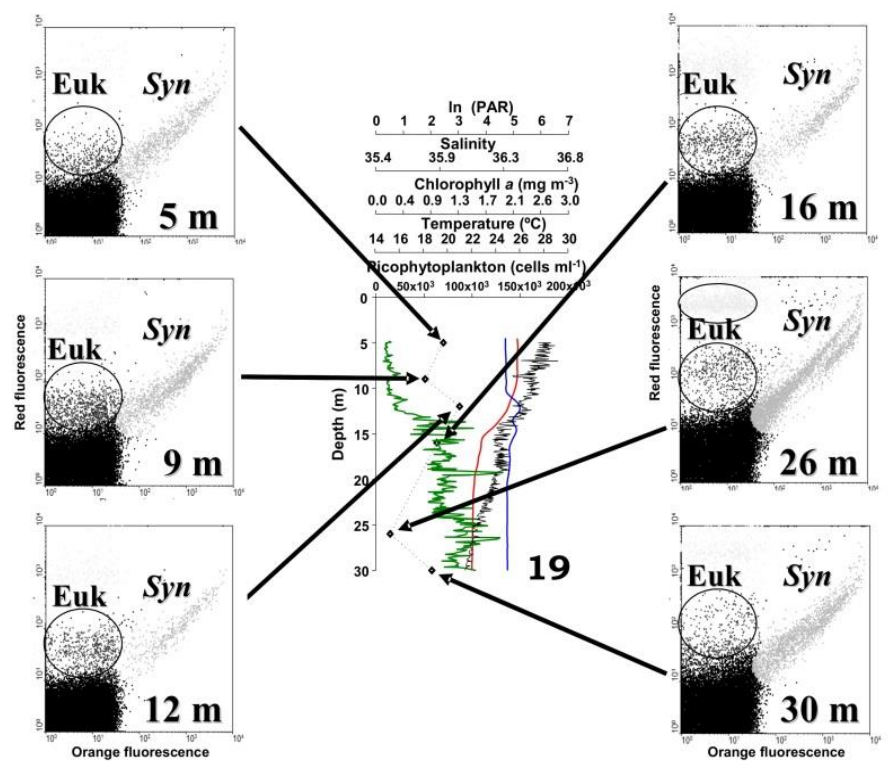

Fig. 5. Cytograms (orange fluorescence vs. red fluorescence) of samples in Station 19 (close to the Coatzacoalcos River), at different depths, and their relation to the profiles of some variables. At $26 \mathrm{~m}$, there are two picoekaryote populations (encircled). Syn = Synechococcus, Euk = Unidentified picoeukaryote populations. 


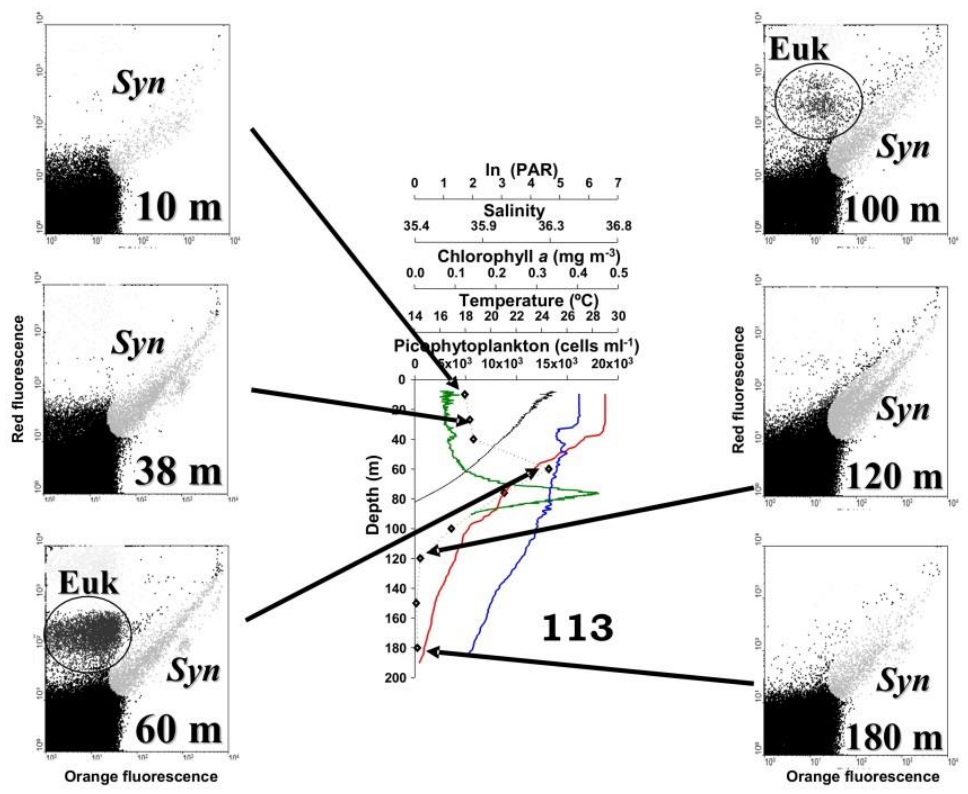

Fig. 6. Same legend as Fig. 5, for samples in Station 113 (Campeche Canyon).Syn = Synechococcus, Euk = Unidentified picoeukaryote population.

The highest picophytoplankton abundance $\left(1.67 \times 10^{5}{\left.\text { cells } \mathrm{ml}^{-1}\right)}^{-1}\right.$ was detected in a coastal area, in shallow waters in the vicinity of the GrijalvaUsumacinta Rivers (Sta. 76, $9 \mathrm{~m}$ ), followed by the abundance found in another coastal area, near the mouth of the Coatzacoalcos River $\left(1.19 \times 10^{5} \mathrm{cells} \mathrm{ml}^{-1}\right.$, Sta. 17, $5 \mathrm{~m}$ ), whereas in the Campeche Canyon picophytoplankton abundances reached a maximum of $1.53 \times 10^{4}$ cells ml $^{-1}$ (Sta. 102, $10 \mathrm{~m}$ ) (Table 1$)$.

Additionally, the vertical distributions of picophytoplankton showed a weak correspondence with those of the chlorophyll $a$. Only at Station 11 was there a close association ( $1 \mathrm{~m}$ difference) between the $\mathrm{CM}$ and maximum cell PFP abundance (Fig. 3), and although the distribution patterns of both vertical distributions (picophytoplankton and chlorophyll a) were similar at Stations 108 and 113 (showing a deep maximum concentration), these peaks did not coincide and were $20 \mathrm{~m}$ apart, with the PFP maximum concentration above the CM (Fig. 3).

Close to the CoatzacoalcosRiver, picophytoplankton varied in the water column from $5.82 \times 10^{4}$ to $1.19 \times 10^{5}$ cells ml ${ }^{-1}$ peaking between 5 and $32 \mathrm{~m}$ depth (Fig. 3, Table 1). In this area, maximum cell abundance occurred in the mixed layer, except at Station 11.

Over the continental shelf near the GrijalvaUsumacinta Rivers PFP concentrations ranged between $9.61 \times 10^{3}$ and $1.67 \times 10^{5}$ cells $\mathrm{ml}^{-1}$. Highest cell abundance occurred in subsurface waters between 5 and $21 \mathrm{~m}$ depth $\left(24-78 \% \mathrm{PAR}_{0}\right)$ within the mixed layer. Stations had shallow waters where higher picophytoplankton abundance occurred towards the bottom with no relation to the chlorophyll $a$ pattern, except at Station 74.

Picophytoplankton abundances in the oceanic region (Campeche Canyon) ranged between 275 cells ml $^{-1}$ and $1.53 \times 10^{4}$ cells ml ${ }^{-1}$. Maximum cell abundances differed between Stations 108-113 in terms of cell concentration and depth. Station 102 attained its highest cell abundance at $10 \mathrm{~m}$ depth, above the thermocline, whereas Stations 108 and 113 attained up to $1.25 \times 10^{4}$ cells ml $^{-1}\left(68 \% \mathrm{PAR}_{0}\right)$ and $1.32 \times 10^{4}\left(31 \% \mathrm{PAR}_{0}\right)$, respectively, at $60 \mathrm{~m}$ depth, below the mixing layer (Fig. 3, Table 1).

\section{Discussion}

The distribution of total picophytoplankton (PFP) was determined during the "dry season" in the southern Gulf of Mexico and quantitative results in this marine environment indicated higher cell concentrations over the continental shelf than in more oceanic, oligotrophic waters (Campeche Canyon). Higher photosynthetic biomass in coastal waters has been previously documented in the southern Gulf of Mexico (SIGNORET et al., 2006) and suggests that coastal waters provide suitable environmental conditions to maintain natural phytoplankton communities. PFP was found in warm waters (up to $29^{\circ} \mathrm{C}$ ) in the study area and maximum cell abundance occurred in shallow coastal waters (above $10 \mathrm{~m}$ ) at temperatures between 20 and $26^{\circ} \mathrm{C}$. Total PFP was distributed throughout the water column in coastal 
waters (above $100 \mathrm{~m}$, photic zone) and reached a maximum cell concentration of $1.67 \times 10^{5}$ cell ml $\mathrm{m}^{-1}$ at salinities $>35.5$. Schapira et al. (2010) found a higher concentration of PFP $\left(1.3-1.4 \times 10^{6}\right.$ cell ml$\left.~^{-1}\right)$ at lower salinities $(8-11 \%)$ associated with brackish-marine waters in a coastal lagoon in Australia. Since river runoff did not cause a detectable thermal and salinity gradient (freshwater influence) in coastal waters - as salinity values never decreased below 36 throughout the water column - possibly insufficient nutrient availability in the water for the growth of PFP populations occurred over the continental shelf during the dry season.

Temporal and spatial variations of PFP have been previously reported in diverse marine environments worldwide (ALONSO-LAITA et al., 2005). In this study, the distribution of PFP showed higher fluctuations between shallow coastal Stations within the mixed layer than in more oceanic waters of the Campeche Canyon. Rapid physicochemical changes are known to occur at different scales in coastal water (ÁLVAREZ-GÓNGORA et al., 2012) and changes in the dynamic of PFP have been suggested (MOORE and CHISHOLM, 1999; VELDHUIS et al., 2005), as a result of nutrient concentration (RAVEN, 1998), water circulation, seasons, stratification (BOUMAN et al., 2011), grazing (PERNTHALER, 2005), salinity (MITBAVKAR et al., 2012), and light availability in the water column (CHEN et al., 2011). As for the southern Gulf of Mexico, the vertical structure of chlorophyll $a$ (pico, nano, and microphytoplankton) has been postulated as a function of thermal fluxes, haline fronts, irradiance, nutrient uptake, and regional circulation patterns (SIGNORET et al., 2006). In addition, in situ profiles of natural chlorophyllfluorescence in the southern Gulf have revealed that autotrophic communities had maximum growth yield related to both the thermocline and the limit of the euphotic layer (SIGNORET et al., 2006). In general, this study found that total PFP abundance had a weak correspondence with the depth of chlorophyll $a$ maximum (DCM) which suggested that higher photosynthetic cells other than PFP contributed significantly to the DCM.

The transition from oligotrophic waters to nutrient-rich and well-mixed waters in coastal areas has been linked to an increasing concentration of Synechococcus and picoeukaryotes (ANSOTEGUI et al., 2003; GUILLOU et al., 2004; NOT et al., 2004). This has been also reported in the southern Gulf of Mexico, where the photosynthetic pigments zeaxanthin (representing Synechococcus) and prasinoxanthin (representing picoprasinophytes) reached high concentrations towards coastal waters influenced by nutrient loads (HERNÁNDEZBECERRIL et al., 2012). Therefore, this suggests that the major abundance of coastal PFP reported here may be assigned to the presence of Synechococcus and picoeukaryote populations. However, it is not clear what the PFP contribution to biomass is, since chlorophyll $a$ concentrations (CM) had little relationship to PFP abundance in the water column at most Stations.

Some PFP species (picoprokaryotes) have developed physiological adaptations that link them to certain ecological niches in the environment. For example, Prochlorococcus is known by at least two physiologically and genetically different ecotypes in the water column: one adapted to high light conditions and another to low light conditions (BOUMAN et al., 2011). As for the coastal and oceanic waters of the Gulf of Mexico, the specific divinyl-chlorophyll $a$ marker has suggested high cell concentrations of Prochlorococcus (above and below $1 \% \mathrm{PAR}_{0}$ ) in winter (HERNÁNDEZ-BECERRIL et al., 2012), although little is yet known of PFP ecotypes in terms of function, distribution, and contribution to total biomass in Mexican waters. Physiological adaptations of PFP in the water column to light conditions, nutrient availability, and temperature have been discussed in some studies and their advantages have been associated with the distribution of these organisms in diverse environments (ANDERSSON et al., 1994; RAVEN, 1998; MOORE and CHISHOLM, 1999; VELDHUIS et al., 2005).

Oligotrophic waters have been regarded as a suitable environment for the growth and numerical dominance of PFP within the phytoplankton community (HALL and VINCENT, 1990; GOERICKE and REPETA, 1992; CROSBIE and FURNAS, 2001). For instance, in offshore waters of the southern Adriatic Sea, Cerino et al. (2012) determined that PFP organisms, mainly picoprokaryotes, were the most important phototrophic fraction with $96 \%$ of total abundance and up to $49 \%$ of total biomass. In oligotrophic waters of the Campeche Canyon, PFP showed still moderate

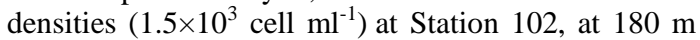
(Fig. 3), as previously reported in other regions (PARTENSKY et al., 1999; LANDRY, 2002; CHEN et al., 2011), although concentrations were up to 3 orders of magnitude lower than those recorded in coastal areas. Moreover, the peak of PFP in oligotrophic waters was above the CM ( 20 m), which also suggested the potential dominance of larger photosynthetic forms (e.g. nano or microphytoplankton, diatoms, etc.) over PFP.

In the oligotrophic waters of southern subtropical basins of the Pacific, Indian and Atlantic Oceans, Bouman et al.(2011) found that the abundance and community composition of picophytoplankton (both prokaryotes and eukaryotes) was governed by the development of water stratification that led to a 
remarkable occurrence of picoeukaryotes linked to well-mixed waters whereas Prochlorococcus was substantially predominant along stratified oligotrophic oceanic systems.

Regarding the natural mechanisms of productivity in oligotrophic waters of the southern Gulf of Mexico, Salas-de-León et al.(2004) suggested that the development of the upwelling brings nutrient loads from mid-waters that stimulate the growth of autotrophic organisms triggering unimodal DCM (up to $0.32 \mathrm{mg} \mathrm{m}^{-3}$ ) at depths $\sim 1 \% \mathrm{PAR}_{0}$ (78-89 $\mathrm{m} \mathrm{depth}$ ). Although the structure of DCM reported in this study coincided with that given in previous studies, surprisingly higher concentrations at the DCM (up to $0.49 \mathrm{mg} \mathrm{m}^{-3}$ ) were detected in oligotrophic waters than in either coastal areas or in other studies of the Gulf. Furthermore, a bimodal chlorophyll $a$ distribution (both with $0.35 \mathrm{mg} \mathrm{m}^{-3}$ ) occurred in the Campeche Canyon (Station 102), within the mixed layer and $\sim 1 \%$ $\mathrm{PAR}_{0}$. This study was, however, limited to determining both the physical mechanisms and autotrophic components involved in the DCM in the Campeche Canyon.

The picoprokaryotes Prochlorococcus and Synechococcus were identified in the study area by TEM, but cell counts made no distinction between the abundances and contributions of picoprokaryotes and picoeukaryotes to total PFP abundance. Picoeukaryote populations (even two different populations were detected, Fig. 5) were also detected by flow cytometry in the southern Gulf of Mexico (Figs 5, 6), which agrees with the report of Hernández-Becerril et al. (2012), though we were unable to identify them by TEM.

PFP populations have been poorly investigated in the southern Gulf of Mexico and this study suggests that the picoprokaryotes Prochlorococcus and Synechococcus may be important photosynthetic components for organic carbon production within trophic webs in both coastal and oceanic waters. In other regions elsewhere in the world, Prochlorococcus and Synechococcus usually contribute above $70 \%$ of the total phytoplankton community (CROSBIE and FURNAS, 2001; CERINO et al., 2012), with cell abundances ranging between $10^{4}-10^{5}$ (CHISHOLM et al., 1988) and $10^{3}-10^{5}$ cells $\mathrm{ml}^{-1}$ (GROB et al., 2007), respectively.

In conclusion, PFP populations in the southern Gulf of Mexico showed high variability in coastal waters, possibly as a result of the influence of the mixed layer, irradiance, and nutrient availability. Although peaks of PFP abundances were detected in both coastal and more oceanic areas, those found in the oceanic areas were located deeper $(60 \mathrm{~m})$ in the water column, relatively closer to the DCM (located at about $75 \mathrm{~m}$ ). During the dry season the abundances of PFP yielded higher concentrations in coastal areas than in oligotrophic ones. However, quantitative results of total PFP had little or no relationship with either maximum cell abundance or maximum chlorophyll $a$ which suggests that larger photosynthetic forms may be an important biological component in the southern Gulf of Mexico during the dry season. Prochlocoroccus and Synechococcus were identified and illustrated by TEM, and at least Synechococcus and two unidentified picoeukariote populations were also recognized by flow cytometry. Further studies are required to establish the importance and contribution of PFP (picoprokaryotes and picoeukaryotes) to the total phytoplankton community in different seasons and environments in the southern Gulf of Mexico.

\section{ACKNOWLEDGEMENTS}

We wish to thank the Coordinación de la Investigación Científica (CTIC, UNAM) for their support for our use of the R/V "Justo Sierra" for the PROMEBIO IX cruise. This research project was funded by the Mexican Consejo Nacional de Ciencia y Tecnología (CONACyT) through grant G27777-B.

\section{REFERENCES}

AGAWIN, N. S. R.; AGUSTÍ, S. Prochlorococcus and Synechococcus cells in the central Atlantic Ocean: distribution, growth and mortality (grazing) rates. Vie Milieu, v.55, n. 3/4, p. 165-175, 2005.

ALONSO-LAITA, P.; NAVARRO, N.; DUARTE, C. M. ; AGUSTÍ, S. Seasonality of pico-phytoplankton abundance and cell death in a Mediterranean Bay (Bay of Palma, Majorca Island). Vie Milieu, v.55, n. 3/4, p. 177$184,2005$.

ÁLVAREZ-GÓNGORA, C. C.; LICEAGA-CORREA, M. D.; HERRERA-SILVEIRA, J. A. Seasonal variations of community structures phytoplankton in groundwater discharge areas along the Northern Yucatan Peninsula coast. Rev. Biol. Trop., v. 60, n. 1, p. 157-72, 2012.

ANDERSSON, A.; HAECKY, P.; HAGSTRÖM, Å. Effect of temperature and light on the growth of micro-plankton nano-plankton and pico-plankton: impact on algal succession. Mar. Biol., v. 120, n. 4, p. 511-520, 1994.

ANSOTEGUI, A.; SAROBE, A.; TRIGUEROS, J. M.; URRUTXURTU, I.; ORIVE, E. Size distribution of algal pigments and phytoplankton assemblages in a coastalestuarine environment: contribution of small eukaryotic algae. J. Plankton Res., v. 25, n. 4, p. 341-355, 2003.

BERTILSSON, S.; BERGLUND, O.; PULLIN, M. J.; CHISHOLM, S. W. Release of dissolved organic matter by Prochlorococcus. Vie Milieu, v. 55, n. 3/4, p. 225331, 2005.

BOUMAN, H. A.; ULLOA, O.; BARLOW, R.; LI, W. K. W.; PLATT, T.; ZWIRGLMAIER, K.; SCANLAN, D. J.; SATHYENDRANATH, S. Water column stratification governs the community structure of subtropical marine picophytoplankton. Environ. Microbiol. Rep., v. 3, n. 4, p. 473-482, 2011. 
CERINO, F.; AUBRY, F. B.; COPPOLA, J.; FERLA, R. L.; MAIMONE, G.; SOCAL, G.; TOTTI, C. Spatial and temporal variability of pico-, nano- and microphytoplankton in the offshore waters of the southern Adriatic Sea (Mediterranean Sea). Cont. Shelf Res., v. 44, sp. iss., p. 94-105, 2012.

CHEN, B. Z.; WANG, L.; SONG, S. Q.; HUANG, B. Q.; SUN, J.; LIU, H. B. Comparisons of picophytoplankton abundance, size, and fluorescence between summer and winter in northern South China Sea. Cont. Shelf Res., v. 31, n. 4, p. 1527-1540, 2011.

CHISHOLM, S. W.; OLSON, R. J.; ZETTLER, E. R.; GOERICKE, R.; WATERBURY, J. B.; WELSCHMEYER, N. A. A novel free-living prochlorophyte abundant in the oceanic euphotic zone. Nature, v. 334, n. 6180, p. 340-343, 1988.

CONAGUA, SEMARNAT. Gobierno Federal. Secretaría de Medio Ambiente y Recursos Naturales. Programa Nacional Hídrico: 2007-2012. México: CONAGUA, SEMARNAT, 2008. $159 \mathrm{p}$.

CROSBIE, N. D.; FURNAS, M. J. Abundance, distribution and flow-cytometric characterization of picophytoprokaryote populations in central $\left(17^{\circ} \mathrm{S}\right)$ and southern $\left(20^{\circ} \mathrm{S}\right)$ shelf waters of the Great Barrier Reef. J. Plankton Res., v. 23, n. 8, p. 809-828, 2001.

ESPINOSA-FUENTES, M. L.; FLORES-COTO, C. Crossshelf and vertical structure of ichthyoplankton assemblages in continental shelf waters of the Southern Gulf of Mexico. Estuarine, Coastal Shelf Sci., v. 59, n. 2, p. 333-352, 2004.

GOERICKE, R.; REPETA, D. J. The pigments of Prochlorococcus marinus: the presence of divinyl chlorophyll-a and chlorophyll-B in a marine prokaryote. Limnol. Oceanogr., v. 37, n. 2, p. 425-433, 1992.

GROB, C.; ULLOA, O.; CLAUSTRE, H.; HUOT, Y.; ALARCÓN, G.; MARIE, D. Contribution of picoplankton to the total particulate organic carbon concentration in the eastern South Pacific. Biogeosciences,v. 4, n. 5, p. 837-852, 2007.

GUILLOU, L.; EIKREM, W.; CHRETIENNOT-DINET, M. J.; LE GALL, F.; MASSANA, R.; ROMARI, K.; PEDROS-ALIÓ, C.; VAULOT, D. Diversity of picoplanktonic prasinophytes assessed by direct nuclear SSU rDNA sequencing of environmental samples and novel isolates retrieved from oceanic and coastal marine ecosystems. Protist, v. 155, n. 2, p. 193-214, 2004.

HALL, J. A.; VINCENT, W. F. Vertical and horizontal structure in the picoplankton communities of a coastal upwelling system. Mar. Biol., v. 106, n. 3, p. 465-471, 1990.

HERNÁNDEZ-BECERRIL, D. U.; GARCÍA-RESÉNDIZ, J. A.; SALAS-DE-LEÓN, D. A.; MONREAL-GÓMEZ, M. A.; SIGNORET-POILLON, M.; ALDECORAMÍREZ, J. Nanoplankton fraction in phytoplankton structure from the southern Gulf of Mexico (April 2000). Cienc. Mar., v. 34, n. 1, p. 77-90, 2008.

HERNÁNDEZ-BECERRIL, D. U.; AQUINO-CRUZ, A.; SALAS-DE-LEÓN, D. A.; SIGNORET-POILLON, M.; MONREAL-GÓMEZ, M. A. Studies on picophytoplankton in the southern Gulf of Mexico: pigment analysis and potential importance of the picoeukariote Prasinophyte Micromonas pusilla. Mar. Biol. Res., v. 8, n. 4, p. 331-340, 2012.
LANDRY, M. R. Integrating classical and microbial food web concepts: evolving views from the open-ocean tropical Pacific. Hydrobiologia, v. 480, n. 1/3, p. 29-39, 2002.

LE GALL, F.; RIGAUT-JALABERT, F.; MARIE, D.; GARCZAREK, L.; VIPREY, M.; GOBET, A.; VAULOT, D. Picoplankton diversity in the South-East Pacific Ocean from cultures. Biogeosciences, v. 5, n. 1, p. 203-214, 2008.

MAN-AHARONOVICH, D.; PHILOSOF, A.; KIRKUP, B. C.; LE GALL, F.; YOGEV, T.; BERMAN-FRANK, I.; POLZ, M. F.; VAULOT, D., BÉJÀ, O. Diversity of active marine picoeukaryotes in the Eastern Mediterranean Sea unveiled using photosystem-II psbA transcripts. ISME J., v. 4, n. 8, p. 1044-1052, 2010.

MARIE, D.; SHI, X. L.; RIGAUT-JALABERT, F.; VAULOT, D. Use of flow cytometric sorting to better assess the diversity of small photosynthetic eukaryotes in the English Channel. FEMS Microbiol. Ecol., v. 72, n. 2, p. 165-178, 2010.

MITBAVKAR, S.; RAGHU, C.; RAJANEESH, K. M.; PAVAN, D. Picophytoplankton community from tropical marine biofilms. J. Exp. Mar. Biol. Ecol., v. 426/427, p. 88-96, 2012.

MONREAL-GÓMEZ, M. A.; SALAS-DE-LEÓN, D. A. Circulación y estructura termohalina del Golfo de México, In: LAVÍN, M. F. (Ed.). Contribuciones a la oceanografía física de México. Ensenada: Unión Geofísica Mexicana, 1997. p. 183-199. (Monografía (Unión Geofísica Mexicana); n. 3).

MOON-VAN DER STAAY, S. Y.; DE WACHTER, R.; VAULOT, D. Oceanic 18S rDNA sequences from picoplankton reveal unsuspected eukaryotic diversity. Nature, v. 409, n. 6820, p. 607-610, 2001.

MOORE, L. R.; CHISHOLM, S. W. Photophysiology of the marine cyanobacterium Prochlorococcus: ecotypic differences among cultured isolates. Limnol. Oceanogr., v. 44, n. 3, p. 628-638, 1999.

NOT, F.; DEL CAMPO, J.; BALAGUÉ, V.; DE VARGAS, C.; MASSANA, R. New insights into the diversity of marine picoeukaryotes. PLoS ONE, v. 4, n. 9, p. E7143, 2009.

NOT, F.; LATASA, M.; MARIE, D.; CARIOU, T.; VAULOT, D.; SIMON, N. A single species, Micromonas pusilla (Prasinophyceae), dominates the eukaryotic picoplankton in the western English channel. Appl. Environ. Microbiol., v. 70, n. 7, p. 4064-4072, 2004.

PARTENSKY, F.; HESS, W. R.; VAULOT, D. Prochlorococcus, a marine photosynthetic prokaryote of global significance. Microbiol. Mol. Biol. Rev., v. 63, n. 1, p. 106-127, 1999.

PERNTHALER, J. Predation on prokaryotes in the water column and its ecological implications. Nat. Rev.Microbiol., v. 3, n. 7, p. 537-546, 2005.

RAVEN, J. A. The twelfth Tansley Lecture. Small is beautiful: the picophytoplankton. Funct.Ecol., v. 12, n. 4, p. 503-513, 1998.

RUIZ-FERNÁNDEZ, A. C., SANCHEZ-CABEZA, J. -A.; ALONSO-HERNÁNDEZ, C.; MARTÍNEZ-HERRERA, V.; PÉREZ-BERNAL, L. H.; PREDA, M.; HILLAIREMARCEL, C.; GASTAUD, J.; QUEJIDO-CABEZAS, A. J. Effects of land use change and sediment 
mobilization on coastal contamination (Coatzacoalcos River, Mexico). Cont. Shelf Res., v. 37, p. 57-65, 2012.

SALAS-DE-LEÓN, D. A.; MONREAL-GÓMEZ, M. A.; SIGNORET, M.; ALDECO, J. Anticyclonic-cyclonic eddies and their impact on near-surface chlorophyll stocks and oxygen supersaturation over the Campeche Canyon, Gulf of Mexico. J. Geophys. Res.: Oceans, v. 109, n. C5, p. C05012, 2004.

SALAS-DE-LEÓN, D. A.; MONREAL-GÓMEZ, M. A.; DÍAZ-FLORES, M. A.; SALAS-MONREAL, D.; VELASCO-MENDOZA, H.; RIVERON-ENZASTIGA, M. L.; ORTIZ-ZAMORA, G. Role of near-bottom currents in the distribution of sediments within the Southern Bay of Campeche, Gulf of México. J. Coastal Res., v. 24, n. 6, p. 1487-1494, 2008.

SANVICENTE-AÑORVE, L.; FLORES-COTO, C.; CHIAPPA-CARRARA, X. Temporal and spatial scales of ichthyoplankton distribution in the southern Gulf of Mexico. Estuarine, Coastal Shelf Sci., v. 51, n. 4, p. 463-475, 2000.

SCHAPIRA, M.; BUSCOT, M. -J.; POLLET, T.; LETERME, S. C.; SEURONT, L. Distribution of picophytoplankton communities from brackish to hypersaline waters in a South Australian coastal lagoon. Saline Syst., v. 6, p.2, 2010.

SIGNORET, M.; MONREAL-GÓMEZ, M. A.; ALDECO, J.; SALAS-DE-LEÓN, D. A. Hydrography, oxygen saturation, suspended particulate matter, and chlorophylla fluorescence in an oceanic region under freshwater influence. Estuarine, Coastal Shelf Sci., v. 69, n. 1/2, p. 153-164, 2006.

STOCKNER, J. G. Phototrophic picoplankton: an overview from marine and freshwater ecosystems. Limnol. Oceanogr., v. 33, n. 4, p. 765-775, 1988.
TOLEDO, O. A. Caracterización ambiental del Golfo de México. In: BOTELLO, A. V.; ROJAS-GALAVIZ, J. L.; BENÍTEZ, J. A.; ZÁRATE-LOMELÍ, D. (Eds.). Golfo de México, contaminación e impacto ambiental: diagnóstico y tendencias. Campeche: Universidad Autónoma de Campeche, 1996. p. 9-28. (EPOMEX. Serie Científica; 5).

TORRES-BEJARANO, F.; RAMIREZ, H.; RODRÍGUEZ, C. A study case of hydrodynamics and water quality modelling: Coatzacoalcos River, Mexico. In: SCHULZ, H. E.; SIMÕES, A. L. A.; LOBOSCO, R. J. (Eds.). Hydrodynamics: natural water bodies. [S.1.]: InTech, 2012. cap. 3, p. 49-66. Available at: http://www.intechopen.com/books/hydrodynamicsnatural-water-bodies/. Accessed in: Aug.22, 2012.

VELDHUIS, M. J. W.; TIMMERMANS, K. R.; CROOT, P.; VAN DER WAGT, B. Picophytoplankton: a comparative study of their biochemical composition and photosynthetic properties. J. Sea Res., v. 53, n. 1/2, p. 7 24. 2005

YÁÑEZ-ARANCIBIA, A.; DAY, J. W. The Gulf of Mexico: towards an integration of coastal management with large marine ecosystem management. Ocean Coastal Manage., v. 47, n. 11/12, p. 537-563, 2004.

(Manuscript received 25 February 2013; revised 30 November 2013; accepted 09 December 2013) 